UDC 338.4:658.2

DOI: https://doi.org/10.31651/2076-5843-2020-4-35-43

\section{ZOS-KIOR Mykola}

Dr. Sc. (Ekon.), Professor, Poltava State Agrarian Academy, Poltava, Ukraine

ORCID ID: https://orcid.org/0000-0001-8330-2909 zoskior@gmail.com

\section{ILIN Valerii}

Dr. Sc. (Ekon.), Professor, Kyiv National Economic University named after Vadym Hetman, Kyiv, Ukraine

ORCID ID: https://orcid.org/0000-0002-4223-1865 villin2015@gmail.com
LESYUK Vladyslav

Applicant for Higher Education, Poltava State Agrarian Academy, Poltava, Ukraine

ORCID ID: https://orcid.org/0000-0002-8370-6513 vladlesyuk@gmail.com

\section{KOZLENKO Inna}

Applicant for Higher Education, Poltava State Agrarian Academy, Poltava, Ukraine

ORCID ID: https://orcid.org/0000-0001-7620-2811 innakozlenko1@gmail.com

\title{
POTENTIAL MANAGEMENT OF AGRO-FOOD ENTERPRISES: ANALYSIS OF MEGATRENDS
}

The article summarizes the theoretical aspects of the concept of "megatrend". The concept is considered of "megatrend" from different perspectives. As a result, the megatrend can be understood as a dynamic development of the world economy, encompassing all subjects of the global economic space, which are manifested over a long time and are projected into the future. The confectionery industry is one of the most developed food industry in Ukraine. The dynamics of net sales and the number of plants of Ukrainian and world confectionery companies is analyzed. Megatrends affecting the confectionery industry in Ukraine are analyzed in their global importance and have global vertical and horizontal branches, accordingly offering new options for opportunities for Ukrainian companies. The factors determining the emergence of megatrends in the world economy have been determined. The tasks of companies influenced by megatrends have been identified. Confectionery companies need to monitor and take into account megatrends in solving these tasks. It is important to build an effective system of relationships to use the existing potential and ensure the development of the company in the direction of the megatrend, since this can be a source of competitive advantage and create conditions for overcoming threats to the environment. The factors that must be taken into account in the application and implementation of megatrends in the confectionery industry in Ukraine are highlighted. The megatrends influencing the Ukrainian confectionery manufacturers have been identified.

Key words: potential, megatrends, confectionery industry, management, agro-food enterprises.

Introduction. The effective functioning of the modern world economy and the activities of national and transnational companies are conditioned by the integration of behavior of megatrends in their strategy. Respectively, the long-term strategy of socio-economic development of the world depends on accurate identification of upcoming development of megatrends that were emerged as tendency and patterns of historical development.

The confectionery industry of Ukraine is sensitive to external megatrends of the world confectionery market, because, apart from providing its own market products, it is broadly export oriented. Even the geographical location of Ukraine contributes to the active influence of various megatrends on the domestic confectionery market, forcing local producers to apply new interacting methods with customers. Consequently, the importance of monitoring and analyzing megatrends in the global confectionery market plays an important role in order to ensure the competitiveness of Ukrainian products, both domestically and internationally.

The current challenges that face global world and the trends, that affect Ukraine too, raise a number of global problems and tasks that need urgent consideration. That is why the consideration of global megatrends is gradually gaining in popularity and is the subject of widespread scientific debate by scholars in various fields of knowledge. 
Literature review. Works of mostly foreign and partially domestic scientists are devoted to the research of megatrends, including: O. V. Inshakov [3], E. S. Pankratova [4], A. P. Punchenko [5], J. Benjamin [6], L. Brabandere [7], J. Naisbitt [12], G. Traitler [13], I. Hnatenko [9-11], D. Zilberman [14] and others.

The purpose of the article is to substantiation of theoretical and methodical provisions of management of potential of the enterprises of agro-food sphere on the basis of the analysis of megatrends.

Results and discussion. Existent global trends that are comprehensive are capable of influencing the vast majority of socio-economic processes, thereby forming the vectors of global community development. The influencing trends are different in nature and scale. The biggest trends that are global in nature can be grouped into one category, collectively called "megatrends".

The promoter of the term "megatrend" is John Naisbitt, who published the book "Megatrends: Ten New Directions Transforming Our Lives" in 1982, focusing on the analysis of 10 megatrends that define the face and essence of "new" American society for two decades to come. Despite this, there is no single definition for the term "megatrends".

The essence of the concept of "megatrend" is interpreted in different ways (table 1).

Table 1

The concept of "megatrend"

\begin{tabular}{|l|l|}
\hline \multicolumn{1}{|c|}{ Source } & \multicolumn{1}{c|}{ Definition of the concept } \\
\hline John Naisbitt & $\begin{array}{l}\text { The main directions of the movement, which determine the appearance and } \\
\text { essence of a changing society }\end{array}$ \\
\hline Luc de Brabandere & $\begin{array}{l}\text { A substantial social, economic, political, environmental or technological change that is } \\
\text { likely to have a major impact on a wide range of areas }\end{array}$ \\
\hline Frost \& Sullivan & $\begin{array}{l}\text { Global, sustained, macroeconomic forces of development that affect business, } \\
\text { economies, societies, cultures, and personal lives. In essence, these trends such as } \\
\text { urbanization, connectivity and convergence will define our future world }\end{array}$ \\
\hline Arthur D. Little & $\begin{array}{l}\text { An inevitable evolution leading to a change of society, business, economics or } \\
\text { environment }\end{array}$ \\
\hline PwC & $\begin{array}{l}\text { Macroeconomic and geostrategic forces that are shaping the world. They are factual } \\
\text { and often backed by verifiable data. By definition, they are big and include some of } \\
\text { society's biggest challenges and opportunities }\end{array}$ \\
\hline
\end{tabular}

Source: generalized by the author according to the data $[8 ; 10, p .13 ; 11 ; 12 ; 13]$

As a result, the megatrend can be understood as a dynamic development of the world economy, encompassing all subjects of the global economic space, which are manifested over a long time and are projected into the future. At the same time, accepting the world economy as a complex managed system, the cybernetic principle of feedback must be accepted automatically, which means that the subject determines the development of the environment, and the environment forms the potential of development for the subjects.

Therefore, the megatrend can be viewed from different perspectives (fig. 1).

The latter approach is a complex one, because it combines the two previous ones, that is why it is difficult to embody it since it requires methods of historical and empirical analysis, synthesis of logic, induction and deduction for its implementation.

Megatrends can also be considered as a form of expression of a set of tendencies that act as a complex interconnection between trends of different realms of social reality on a megascale. Each tendency has its own vector, which is composed as a sum total on megalevels of interaction between macroeconomic systems. Therefore, the megatrend usually appears in a separate system, which becomes a kind of multiplier of its distribution. Interaction generated even in one macrosystem and perceived by other macrosystems is systemic in nature. Due to this effect, there is a synergy of the general movement on the most powerful trend [3, p. 62]. 


\section{Megatrend}

As a historical phenomenon, that is a reflection of a number of events that have taken place in the past, and thus manifests a sequence of previous states of society

As a cause of the phenomenon, that precedes any change of the form of the prototype of the future

As a chain of previous events projected into the future in the correlation of historical and futurological aspects

\section{Fig. 1. Megatrend from different perspectives}

Source: author's development

In this manner, the world is developing under the influence of both long-term changes and situational factors, which largely determine the recurring global economic tendencies. The isolation of the content of megatrends is still a particular difficulty, as it is usually defined in a multidisciplinary way, inextricably incorporating environmental, technological, economic and sociological components. The task of science is to emphasize the concept of megatrend and to create a scientific apparatus for its study, considering the integral nature of this object.

It is necessary to specify by industry and country to determine the positions and assess the status of the subjects, power and activity of the driving forces of each megatrend in the global space in analyzing megatrends. Unquestionably, technological and economic megatrends are closely interconnected, which implies "synergistic" opportunities between them. Howsoever, we observe not only production and sales technologies evolving, but also cultural values and social conditions for the implementation of megatrends.

The confectionery industry is one of the most developed food industry in Ukraine. The analysis of the state and prospects of the development of the confectionery market in Ukraine shows that the premier source of supply in the market is domestic production, its production is $95 \%$ in total. The domestic market is highly concentrated, employing nearly 800 companies [2, p. 46].

The list of 100 largest sweets producers in the world includes 4 companies from Ukraine: Roshen, AVK, Millennium and Konti (fig. 2).

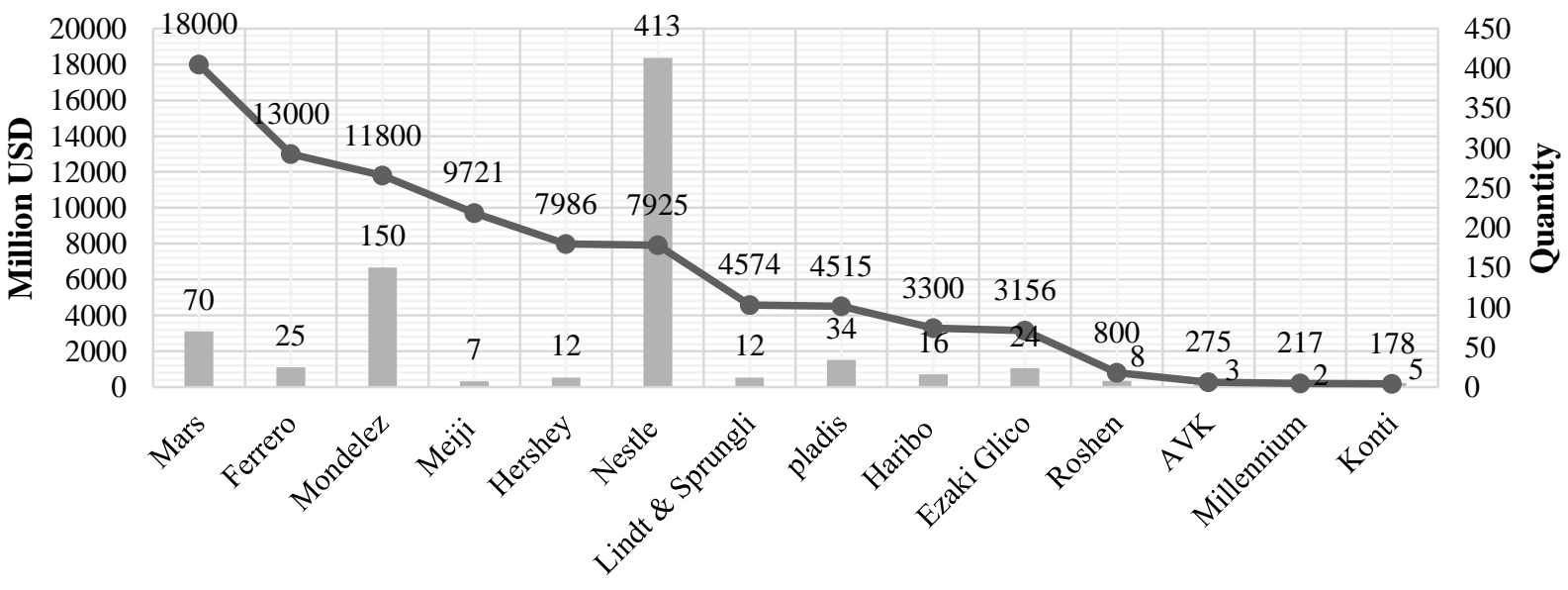

Confectionery companies

Number of Plants $\quad$ Net Sales

Fig. 2. Dynamics of net sales and number of plants of

Ukrainian and 10 largest confectionery companies, 2020

Source: generalized by the author according to the data [9] 
In order to compete successfully in the international and domestic market, Ukrainian manufacturers join the megatrends that occur in the global confectionery market.

Megatrends affecting Ukrainian confectionery manufacturers are [1; 2, p. 49; 6]:

1. Minimalism. Products do not need to be superfluous. The packaging has one logo, no additional elements. The box is transparent sometimes and presents the product in all its glory.

2. Latinization. Almost all the products of Ukrainian manufacturers exporting confectionery products to foreign markets have changed their usual Ukrainian Cyrillic names to often English, or simply Latin.

3. Environmental friendliness. All the big players in the market play on this topic. Promotion of the naturalness of the product and its packaging is widely used by advertising companies. Thus, brands occupy an important social niche and increase customer loyalty. Besides the materials such as cardboard but also the chosen color palette helps to emphasize the eco-friendliness of the packaging. Pastel colors (predominance of yellow, green and brown shades) underpin the chosen brand direction. There is a tendency to design products in craft paper. For instance, Roshen chocolates. The visualization of the filling enhances the attractiveness of the product, but overall the packaging is minimalistic.

4. No sugar. A large number of consumers are really concerned about high content of sugar in food. This especially concerns the production of confectionery products, which are the most vulnerable in this segment. Many buyers do not add corresponding products to their diet to reduce white sugar consumption. The European market is interested in expanding its options to produce a worthy and useful alternative. For example, adding brown sugar, sugar substitutes, and sweeteners in their products. The major manufacturers in this segment are mainly represented by AVK and Korona by Mondelez with their chocolate bar. The rest are small confectionery manufacturers. Ukrainian producers mainly use fructose and stevia as sugar substitutes.

5. Grains. The trend towards healthy eating has reached the confectionery industry long time ago. People look for good sweets, high-cocoa chocolate and good additives on store shelves. Thus, chocolates and pastries with the addition of a variety of grains are particularly popular worldwide. European producers use different ingredients as ingredients, cereals, corn flakes, aerial rice and other well-known consumer supplements. These trends were joined by Ukrainian manufacturers too. Nowadays in Ukraine, grain products are presented by Roshen in the form of chocolate bar with sesame.

6. Handmade. Sweets without chemistry and preservatives made at home or in small workshops are popular all over the world. Major manufacturers have decided to play on this and use minimalistic packaging, the main focus of which is still on the product itself.

7. Individual design. Brands are trying to find an approach for every buyer. The customer chooses a sweetness that matches his feelings and emotions at the moment. Products in one series can have completely different design. Big brands try to approach each buyer individually. This way promotes interactive packaging design. Dynamic logos allow each customer to choose their own option.

8. Gift product. Many manufacturers offer original sweets as a gift. Beautiful and composite shapes, luxury in every detail. Despite the widespread demand for minimalism in the design and environmental friendliness of materials, new product options are emerging. For instance, AVK most often prefers non-standard gift wrapping among other Ukrainian manufacturers.

9. Focusing on the brand, not the product. The trend is becoming more widespread as the brand fades into the background and the product itself is made to focus the consumer's attention on the brand, rather than on the manufacturer and its brand.

10. Snack products "on the go". Modern people are accustomed to spend their day actively being in constant motion. Due to this fact, there is a need to buy products that can be consumed without being distracted. Many manufacturers are actively expanding the range of products for snacks "on the go": muffins, rolls, biscuits. This tendency continues to develop.

11. Pink chocolate. Two years ago, the world confectionery market was shaken by the news of the creation of a "fourth type of chocolate" - a ruby, introduced by Barry Callebaut. Made from ruby cocoa beans, according to the manufacturer, collected in different regions of the world, the new product was presented at an exclusive event in Shanghai, and the company has been developing new Ruby sweets for long 13 years. Nestle was first to introduce pink chocolate in Ukraine in the form of a limited edition Kit 
Kat Ruby bar for Silpo supermarkets, and subsequently launched into mass production for the Ukrainian market. Soon this trend was joined by the Ukrainian company Millennium, which launched a series of chocolate bars in pink chocolate under its own Rose Millennium brand.

Thus, the main megatrends affecting Ukrainian manufacturers can be attributed to marketing activities, while the structure of the main products does not change drastically. Manufacturers continue to experiment with product promotion and new flavors, as well as test their new products, including on Ukrainian consumers.

Megatrends affecting the confectionery industry in Ukraine are analyzed in their global importance and have global vertical and horizontal branches, accordingly offering new options for opportunities for Ukrainian companies.

Here are the factors that cause the emergence of megatrends in the world economy (fig. 3 ).

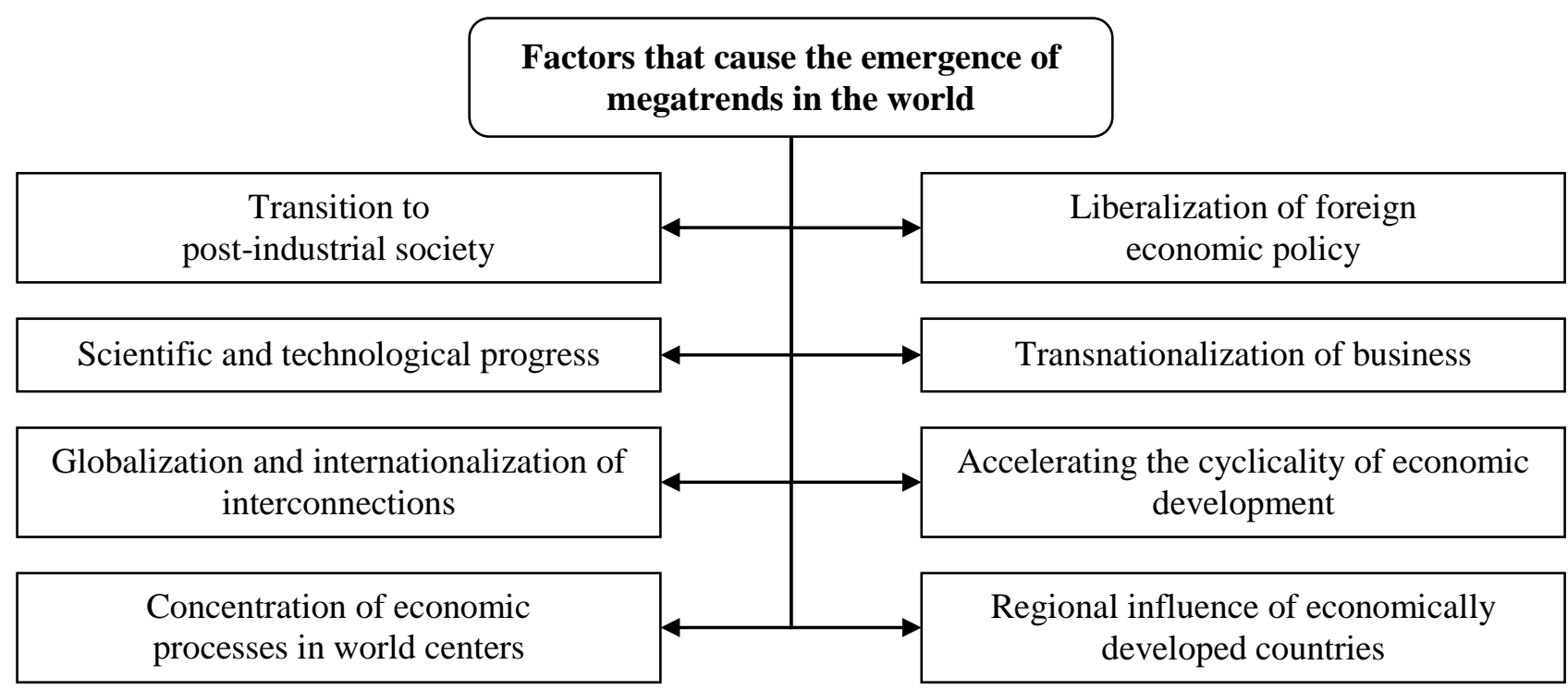

Fig. 3. Factors that cause the emergence of megatrends in the world economy

Source: author's development

It should be noted that not all megatrends reflect the movement of humankind as an "upward elevator", where all related trends are growth and development trends. Such an assessment may be a short-term one, and future re-assessment of the megatrend will show that it was a combined "downward elevator" movement, such as, for example, the modern depletion of natural resources, which was initially perceived as an achievement of mankind, or the use of chemicals in the confectionery industry, which has a negative impact on human health.

In modern conditions, Ukrainian confectionery companies need their own specialists and groups of experts to respond quickly to megatrends, who will be able to develop branded, regional and corporate strategies that will ensure better use of the opportunities provided by globalization.

Confectionery companies need to monitor and take into account megatrends in solving these tasks (fig. 4).

It is important to build an effective system of relationships to use the existing potential and ensure the development of the company in the direction of the megatrend, since this can be a source of competitive advantage and create conditions for overcoming threats to the environment. 


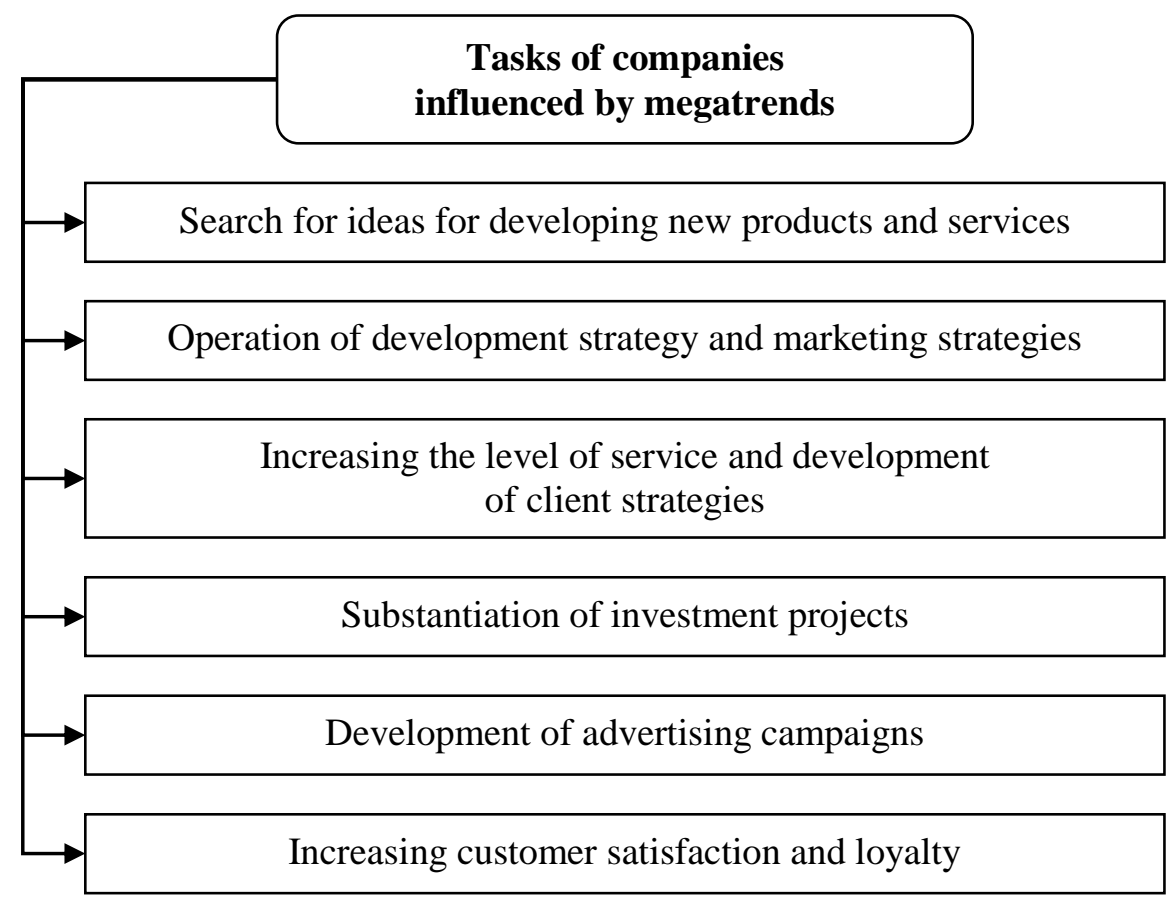

Fig. 4. Tasks of companies influenced by megatrends

Source: author's development

The following factors should be taken into account when applying and implementing megatrends in the confectionery industry in Ukraine:

1. Automation and robotization of production.

2. Technological breakthroughs and digitalization at the global level.

3. Climate change and lack of resources for production.

4. Demographic change: falling birth rates and an aging population.

5. Accelerated urbanization of the population.

6. Redistribution of markets in the world economy.

In this way, we have identified a list of major megatrends affecting the confectionery industry in Ukraine (fig. 5).

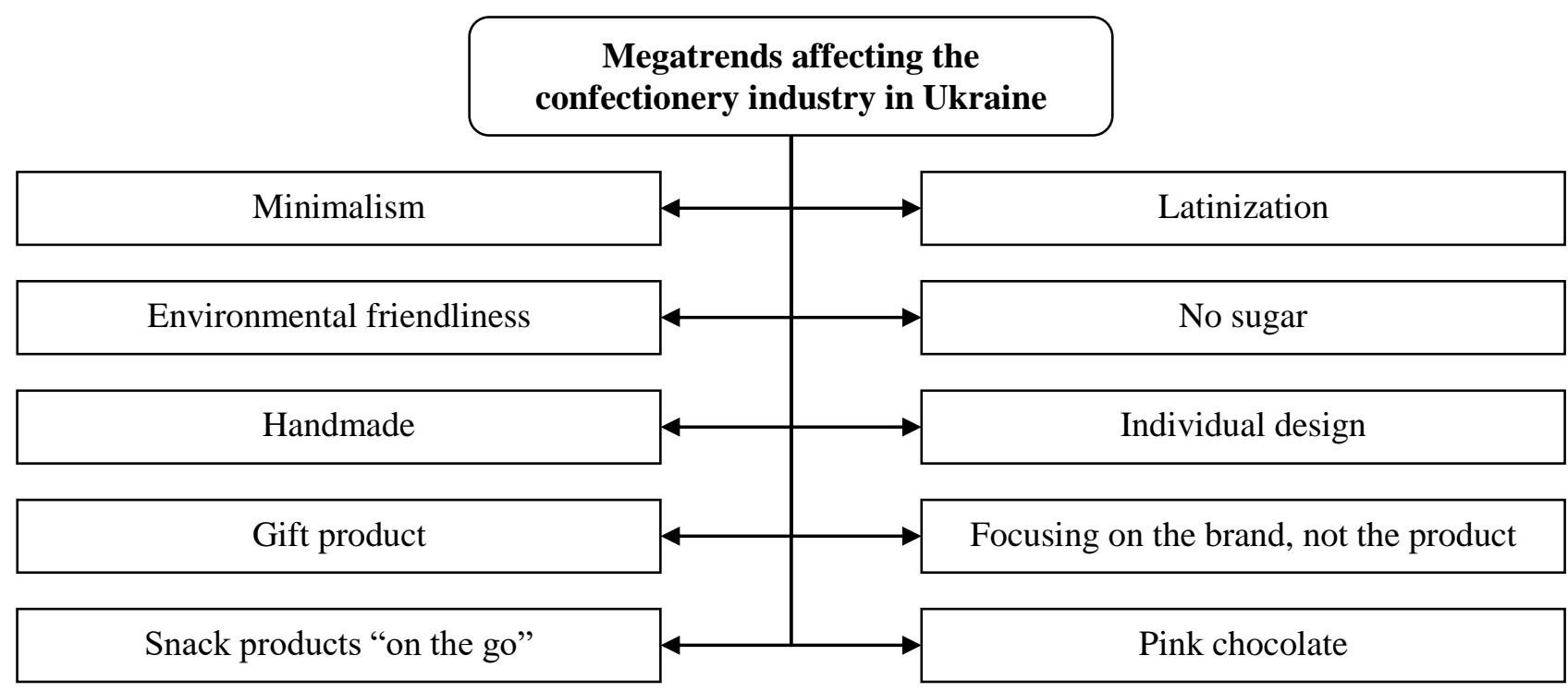

Fig. 5. Megatrends affecting the confectionery industry in Ukraine Source: author's development

Thus, it is expedient for Ukrainian companies to diversify production, looking for new ways of 
development and promotion of production for successful activity in the market of confectionery industry in modern conditions. It is becoming increasingly important to respond quickly to changing market demands, to stop concentrating on one segment. Design, packaging, as well as environmental friendliness of sold products occupy an important place. Ukrainian consumers, as well as foreign ones, want to buy healthy, natural and quality domestic products at an affordable price. In order to win consumers in new segments, there is a need for thorough study of the market and significant financial investments in the development and implementation of marketing strategies of confectionery companies in Ukraine.

Conclusions. The effective functioning of the modern world economy and the activities of national and transnational companies in it is determined by taking into account in their behavior strategy of megatrends. The confectionery industry of Ukraine is sensitive to external megatrends of the world confectionery market, because in addition to providing products for its own market, it is widely exportoriented. The confectionery industry is one of the most developed food industry in Ukraine.

Analysis of the state and prospects of the development of the confectionery market in Ukraine shows that the main source of supply on the market is domestic production, its production is $95 \%$ in total. The domestic market is highly concentrated and employs about 800 companies. The list of the world's 100 largest producers of sweets includes 4 companies from Ukraine: Roshen, AVK, Millennium and Konti. Ukrainian producers join the megatrends that are taking place in the global confectionery market in order to successfully compete in the international and domestic markets.

Megatrends that affect Ukrainian confectionery manufacturers include: minimalism, latinization, environmental friendliness, no sugar, handmade, individual design, gift product, focusing on brand, snack products and pink chocolate. When applying and implementing megatrends in the confectionery industry of Ukraine it is necessary to take into account the following factors: automation and robotization of production; technological breakthroughs and digitalization at the global level; climate change and lack of resources for production; demographic change: falling birth rates and an aging population; accelerated urbanization of the population; redistribution of markets in the world economy.

\section{Список використаних джерел}

1. Аналіз ринку кондитерських виробів України. URL: https://koloro.ua (дата звернення: 11.06.2020).

2. Дем'яненко К. Тенденції розвитку кондитерського ринку України в сучасних умовах. Молодий вчений. 2016. № 9. С. 45-50.

3. Иншаков О. Формирование концепции мегатрендов эволюции глобальной экономической системы. Экономика. Налоги. Право. 2012. № 5. С. 61-70.

4. Панкратова Е. К вопросу о сущности и классификационных видах мегатрендов мирохозяйственного развития. Вестник Ростовского государственного экономического университета. 2012. № 3 (39). C. 31-36.

5. Пунченко О. Глобалізація - основа формування нового інформаційного порядку та модернізації соціальної політики. Вісник Харківського нащіонального університету імені В. Н. Каразіна. 2009. № 15 (861). C. 49-54.

6. Benjamin, J. (1996). Megatrends in Retail Real Estate. Dordrecht: NL. Springer.

7. Brabandere, L. \& Iny, A. (2013). Thinking in New Boxes: A New Paradigm for Business Creativity. New York, NY: Random House.

8. Eagar, R., Boulton, C. \& Demyttenaere, C. (2014). The Trends in Megatrends. Prism, 2, 12-23.

9. Hnatenko, I., Petryk, O., Semenov, A., Samiilenko, A., Rubezhanska, V. \& Patsarniuk, O. (2020). Conceptual model for assessing the investment attractiveness of innovative projects of industrial enterprises. Accounting. №6 (7). P. 1345-1350.

10. Hnatenko, I., Kuksa, I., Naumenko, I., Baldyk, D. \& Rubezhanska, V. (2020). Infrastructure of innovation enterprise: features of formation and regulation in modern market conditions. Management Theory and Studies for Rural Business and Infrastructure Development. №42 (1). P. 97-104.

11. Hnatenko, I., Samborskyi, O., Isai, O., Parkhomenko, O., Rubezhanska, V. \& Yershova, O. (2020). Modeling of foreign direct investment impact on economic growth in a free market. Accounting. №6 (5). P. 705712.

12. Naisbitt, J. (1984). Megatrends: Ten New Directions Transforming Our Lives. New York, NY: 
Warner Books.

13. Traitler, H. (2015). The Food Industry Innovation School: How to Drive Innovation through Complex Organizations. Hoboken, NJ. John Wiley \& Sons.

14. Zilberman, D., Heikes, K. \& Petiard, V. (2018). Megatrends in Food and Agriculture: Technology, Water Use and Nutrition. Hoboken, NJ. John Wiley \& Sons.

15. Zos-Kior, M., Kuksa, I., Samoilyk, I. \& Storoška, M. Methodology for assessing the countries' globalization development (2017). Economic Annals-XXI. №11-12. P. 4-8.

\section{References}

1. KOLORO (2020). Analysis of the confectionery market of Ukraine. URL: https://koloro.ua (Accessed: 11.06.2020).

2. Dem'ianenko, K. (2016). Tendentsii rozvytku kondyterskoho rynku Ukrainy v suchasnykh umovakh [Tendencies in the confectionery market of Ukraine in modern conditions]. Molodyi vchenyi, 9, 45-50.

3. Inshakov, O. (2012). Formirovanie koncepcii megatrendov jevoljucii global'noj jekonomicheskoj sistemy [Formation of the concept of megatrends of evolution of the global economic system]. Jekonomika. Nalogi. Pravo, 5, 61-70.

4. Pankratova, E. (2012). K voprosu o sushhnosti i klassifikacionnyh vidah megatrendov mirohozjajstvennogo razvitija [To the question of the nature and classification types of megatrends of world economic development]. Vestnik Rostovskogo gosudarstvennogo jekonomicheskogo universiteta, 3 (39), 31-36.

5. Punchenko, O. (2009). Hlobalizatsiia - osnova formuvannia novoho informatsiinoho poriadku ta modernizatsii sotsialnoi polityky [Globalization - the basis for the formation of a new information order and modernization of social policy]. Visnyk Kharkivskoho natsionalnoho universytetu imeni $V$. N. Karazina, 15 (861), 49-54.

6. Benjamin, J. (1996). Megatrends in Retail Real Estate. Dordrecht: NL. Springer.

7. Brabandere, L. \& Iny, A. (2013). Thinking in New Boxes: A New Paradigm for Business Creativity. New York, NY: Random House.

8. Eagar, R., Boulton, C. \& Demyttenaere, C. (2014). The Trends in Megatrends. Prism, 2, 12-23.

9. Hnatenko, I., Petryk, O., Semenov, A., Samiilenko, A., Rubezhanska, V. \& Patsarniuk, O. (2020). Conceptual model for assessing the investment attractiveness of innovative projects of industrial enterprises. Accounting, №6 (7), 1345-1350.

10. Hnatenko, I., Kuksa, I., Naumenko, I., Baldyk, D. \& Rubezhanska, V. (2020). Infrastructure of innovation enterprise: features of formation and regulation in modern market conditions. Management Theory and Studies for Rural Business and Infrastructure Development, 42 (1), 97-104.

11. Hnatenko, I., Samborskyi, O., Isai, O., Parkhomenko, O., Rubezhanska, V. \& Yershova, O. (2020). Modeling of foreign direct investment impact on economic growth in a free market. Accounting, 6(5), 705-712.

12. Naisbitt, J. (1984). Megatrends: Ten New Directions Transforming Our Lives. New York, NY: Warner Books.

13. Traitler, H. (2015). The Food Industry Innovation School: How to Drive Innovation through Complex Organizations. Hoboken, NJ. John Wiley \& Sons.

14. Zilberman, D., Heikes, K. \& Petiard, V. (2018). Megatrends in Food and Agriculture: Technology, Water Use and Nutrition. Hoboken, NJ. John Wiley \& Sons.

15. Zos-Kior, M., Kuksa, I., Samoilyk, I. \& Storoška, M. Methodology for assessing the countries' globalization development (2017). Economic Annals-XXI, 11-12, 4-8.

ЗОСБ-КІОР Микола Валерійович

доктор економічних наук, професор,

Полтавська державна аграрна академія,

м. Полтава, Україна

\section{ІЛЬЇН Валерій Юрійович}

доктор економічних наук, професор,

Київський національний економічний університет імені Вадима Гетьмана, м. Київ, Україна 


\section{ЛЕСЮК Владислав Станіславович}

здобувач вищої освіти ОС Магістр,

Полтавська державна аграрна академія,

м. Полтава, Україна

\section{КОЗЛЕНКО Інна Олександрівна}

здобувач вищої освіти ОС Магістр,

Полтавська державна аграрна академія,

м. Полтава, Україна

\section{МЕНЕДЖМЕНТ ПОТЕНЦІАЛУ ПІДПРИЕМСТВ АГРОПРОДОВОЛЬЧОЇ СФЕРИ: АНАЛІЗ МЕГАТРЕНДІВ}

Проблема. Ефективне функціонування сучасної світової економіки і діяльність в ній національних та транснаціональних компаній зумовлюється урахуванням в їх стратегії поведінки мегатрендів. Відповідно довгострокова стратегія сочіально-економічного розвитку світу залежить від правильної ідентифікації майбутнього розвитку мегатрендів, щзо сформувалися як тендениії та закономірності історичного розвитку. Потенціал підприємств агропродовольчої сфери, в тому числі кондитерської галузі Украӥни, є чутливим до зовнішніх мегатрендів світового кондитерського ринку. Сучасні виклики, які стоять перед глобальним світом та тендениіï, під виливом яких перебуває Україна, висувають перед нею цілу низку глобальних проблем та завдань, що потребують термінового розгляду. Саме тому розгляд глобальних мегатрендів поступово набирає все більшої популярності і стає об' 'ктом широкого наукового обговорення вченими різних галузей знань.

Мета. Метою статті є наукове обтрунтування теоретико-методичних положень управління потениіалом підприємств агропродовольчої сфери на основі аналізу мегатрендів.

Результати. Узагальнено теоретичні аспекти до поняття «мегатренд». В результаті під мегатрендом можна розуміти динамічні властивості розвитку світової економіки, що охоплюють всіх суб'єктів глобального економічного простору, які проявляються протягом тривалого часу $i$ проектуються на майбутнє. Розглянуто поняття «мегатренд» з різних точок зору. При аналізі мегатренди необхідно конкретизувати в залежності від галузі та країни для визначення позицій $i$ оцінки стану суб'єктів, потужності і активності рушійних сил кожного з мегатрендів у глобальному просторі. Кондитерська галузь є однією з найрозвинутіших у харчовій промисловості Украӥни. Аналіз стану i перспектив розвитку кондитерського ринку в Украӥні свідчить, що основним джерелом формування пропозиції на ринку є вітчизняне виробнищтво. Проаналізовано динаміку чистого обсягу продажів та кількості заводів украӥнських та світових кондитерських компаній.

Наукова новизна. Наукова новизна одержаних результатів дослідження полягає у розробиі теоретичних положень, методичних та науково-практичних рекомендацій щодо застосування мегатрендів в кондитерській галузі України.

Висновки. Проаналізовані мегатренди, що впливають на кондитерську галузь України, за своӥм значенням глобальні і мають глобальні вертикальні і горизонтальні відгалуження, тим самим пропонуючи нові варіанти можливостей для украӥнських компаній. Визначено чинники, щуо зумовлюють появу мегатрендів у світовій економіці. Кондитерським компаніям необхідно відстежувати та враховувати мегатренди при виріменні поставлених завдань. Визначено завдання компаній на які впливають мегатренди. Важлливо побудувати ефективну систему взаємовідносин для використання наявного потенціалу та забезпечення розвитку компанії в напрямку мегатренду, адже саме це може стати джерелом конкурентної переваги і створити умови для подолання загроз зовнішнього середовища. Виділено фактори, які необхідно враховувати при застосуванні та реалізаиії мегатрендів в кондитерській галузі України. Визначено мегатренди, щэо впливають на українських виробників кондитерських виробів.

Ключові слова: потенціал, мегатренди, кондитерська галузь, менеджмент, підприсмства агропродовольчої сфери.

Одержано редакиією: 20.09.2020

Прийнято до публікаиії: 21.11.2020 